\title{
CLINICAL STUDY TO ASSESS THE EFFECT OF YOGA BASTI IN GRIDHRASI
}

\author{
B.A. Lohith*, Girish K.J
}

Dept of Panchakarma, SDM College of Ayurveda, Hassan, Karnataka, India

Received on: 04/10/12 Revised on: 30/11/12 Accepted on: 18/12/12

\author{
*Corresponding author \\ E-mail: lokithbadr@yahoo.com \\ DOI: $10.7897 / 2277-4343.04123$ \\ Published by Moksha Publishing House. Website www.mokshaph.com \\ All rights reserved.
}

\section{ABSTRACT}

Gridhrasi is one of the most common disorders of Vata and frequently physician is called upon to manage painful condition in clinical practice. Symptoms of Gridhrasi simulate with Sciatica. The present 'Clinical study was carried out to assess effect of yoga Basti in Gridhrasi. As Bastikarma is the most important among the Panchakarma for the management of Vatavyadi. In this clinical study, 10 patients received one sitting of yoga Basti, where five Anuvasana basti with the Sahacharadi taila and three Niruha basti with the Erandamuladi kwatha was administered. In this present study with yoga Basti, $10 \%$ patients were cured. $60 \%$ patients got marked improvement and $30 \%$ patients were improved. None of the patients remained unchanged. Statistically highly significant results were obtained.

Keywords: Gridhrasi, Yoga basti, Sciatica S.L.R test

\section{INTRODUCTION}

Exact data on the incidence and prevalence of sciatica are lacking. In general an estimated $5 \%-10 \%$ of patients with low back pain have sciatica, whereas the reported lifetime prevalence of low back pain ranges from $49 \%$ to $70 \%$. The annual prevalence of disc related sciatica in the general population is estimated at $2.2 \%{ }^{1}$

Improper sitting postures, continuous and overexertion, jerky movements during traveling and sports weight lifting etc., all these factors create an undue pressure over the spinal column and play an important role in producing low backache and sciatica.

Gridhrasi is one among 80 types of Nanatmaja Vatavyadhi. The cardinal signs and symptoms of Gridhrasi (Sciatica) are Ruk (pain), Toda (pricking sensation), Stambha (stiffness) and Muhuspandana (twitching) in the Sphik, Kati, Uru, Janu, Jangha and Pada in order and Sakthikshepa Nigraha ${ }^{2}$ i.e. restricted lifting of the leg. In Kaphanubandhata, Tandra, Gaurva, Arochaka will be present.

The most important symptom of sciatica is lumbosacral radicular leg pain that follows a dermatomal pattern radiating below the knee and into the foot and toes. In sciatica there is pain along the distribution of sciatic nerve which begins from buttock and radiates downwards to the posterior aspect of thigh, calf and to the outer border of foot. Herniation or degenerative changes in inter-vertebral disc is the most common cause. There is often history of trauma, as twisting of the spine, lifting heavy objects or exposure to cold.

Basti is the most important among Panchakarma due to its multiple effects. Pitta and Kapha are dependent on Vata as it governs their functions. Basti is not only best for Vata disorders but also equally effective in correcting the morbid Pitta, Kapha and Rakta. ${ }^{3}$ Charaka has considered, Basti therapy as half of the treatment of all the disease, while some authors consider it as the complete remedy for all the ailments. ${ }^{4}$
Basti is one of the unique procedure explained for the management of Vata vyadhi, where Gridhrasi is being the predominant of Vata dosha, basti is being used widely for the management of Gridhrasi.

\section{Objectives}

To evaluate the efficacy of Erandamuladi niruha and Sahachardi taila as yoga Basti in the management of Gridhrasi.

\section{Source of data}

Drug was collected from S D P Pharmacy, Puttur, Karnataka, India.

10 patients of Gridhrasi fulfilling the criteria for the inclusion were selected for the study from O.P.D and I.P.D, irrespective of their sex, religion, etc.

Diagnostic criteria: Patients with classical features of Gridhrasi such as

- Stambha, Ruk and Toda over the Sphikapoorva, Kati, Prishta, Uru, Janu ,Jangha, Pada, Parshni, Paryanta vedana

- Arochaka

- Saktnoh Utkshepana Vedana

- Dehapravakrata

- Sakthana-hakshepam-nigraniyat (S.L.R. test.)

Inclusion criteria

- Diagnosed cases of Gridhrasi

- Patients between age group 20-60 years of either sex.

- Chronicity of less than three years and without any deformity.

Exclusion criteria

- Contra- indicated for Basti chikista,

- Patients with tuberculosis and malignancy

- Surgical indications such as progressive neurological deficit.

- Fractures of pelvis and femur.

(Extreme disorder like Hypertension, Diabetes mellitus etc. are not included in the study) 


\section{Laboratory investigations}

Blood: Differential leukocyte count, Total leukocyte counts, Erythrocytes sedimentation rate, Hemoglobin (Gram percentage).

Urine: Albumin, microscopic, sugar.

X-ray: Lumbo-sacral region

\section{Treatment protocol}

Patients were administered Basti as per Yoga Basti schedule. Erandamooladi Niruha Basti ${ }^{5}$ and Sahacharadi Tail $^{6}$ Anuvasana Basti were given. One course of Yoga Basti was administered for 8 days, during this period no other internal or external medicine was given except Sthanika Abhyanga and Svedana which is the part of the Purvakarma for Basti.

Preparation and Dosages of Niruha and Anuvasana basti

Niruha Basti: The preparation of Niruha basti was done in the usual manner of Niruha basti.

Dose of Niruha basti

- Eranda Mooladi Kvatha- $190 \mathrm{ml}$

- Kalka- 45 gm

- Gomutra- 90ml

- Honey-90ml

- Sahacharadi taila-140ml

- Saindhava lavana- $5 \mathrm{gm}$

Total: $560 \mathrm{ml}$

Dose of Anuvasana Basti: $75 \mathrm{ml}^{7}$

Basti schedule: One course of yoga Basti was administered as per the schedule, that is

\begin{tabular}{|c|c|c|c|c|c|c|c|c|}
\hline Day & 1 & 2 & 3 & 4 & 5 & 6 & 7 & 8 \\
\hline Basti & A & N & A & N & A & N & A & A \\
\hline
\end{tabular}

\section{Assessment criteria}

The assessment of effect of treatment was done on the basis of clinical changes observed in patients. Numerical score was assigned for each of the following signs and symptoms:

- Pain

- Stiffness

- Pricking sensation

- Numbness

- Fasciculation

- Anorexia

- Heaviness

- S.L.R. test

- Standing

- Distance of walking

Ruk: The mean score of Ruk (pain) was reduced by $58.3 \%$, which was statistically highly significant $(\mathrm{p}<0.001)$

Toda: The mean score of Toda (pricking sensation) was 2 and was reduced by $60.0 \%$ which was statistically significant $(\mathrm{p}<0.02)$.

Stambha: The mean score of Stambha (stiffness) was reduced by $65.3 \%$, which was statistically highly significant $(\mathrm{p}<0.001)$.

Spandana: The mean score of Spandana (fasciculation) was reduced by $50 \%$ which was statistically insignificant $(\mathrm{p}>0.05)$.
Aruchi: The mean score of Aruchi (Anorexia) was reduced by $66.6 \%$ which was statistically insignificant ( $>>0.05)$.

Tandra: The mean score of Tandra (torpor) was reduced by $47.8 \%$ which was statistically insignificant ( $p>0.05$ )

Gaurava: The mean score of Gaurava (Heaviness) was reduced by $60.8 \%$ was statistically insignificant $(p>0.05)$

S.L.R. Test: The mean score of S.L.R. test was reduced by $44 \%$, which was statistically highly significant $(\mathrm{p}<0.001)$.

Standing: The mean score of standing was reduced by $59 \%$, which was statistically highly significant $(\mathrm{p}<0.001)$.

Walking distance: The mean score of walking distance was reduced by $61.0 \%$, which was statistically highly significant $(\mathrm{p}<0.001)$.

\section{DISCUSSION}

\section{Effect on Signs and Symptoms of Gridhrasi}

Patients of Gridhrasi treated with yoga Basti showed that $58.3 \%$ relief in the Ruk, $60 \%$ relief in Toda, $65.3 \%$ relief in Stambha 50.0\% relief in the Spandana, $66.6 \%$ relief in the Aruchi,47.8\% in Tandra, $60.8 \%$ relief in the Gaurava, 44.0 in S.L.R Test, 59\% relief in the Standing and $61.0 \%$ relief in the walking.

Erandamuladi Niruha Basti which contains 34 drugs among them maximum number dravys belongs to Ushna veerya, having the Laghu Ruksha Guans it mainly does Deepana and Lekhana. Which is Indicated in Shula of Janga, Uru, Pada, and Prusta region and it is indicated in Kapha-avrutha conditions, it also does Maruthanigrahana, in case of Mala-mutra sanga, Arsha Anaha and Admana. Sahacharadi Taila which is used for Anuvasna basti containing three drugs among them all are having the Ushna veerya and Kapaha-Vatashamaka properties. It is indicated in difficulty in lower limb causing the altered gaits.

\section{Probable Mode of Action}

Basti dravya enters into the Pakwasaya. It is the place where the water and minerals are absorbed in proximal colon. Sodium and potassium which are essential fundamental factors for nerve impulses and Vitamin B12 which is essential factor for the development and proper functioning of the nervous system are also absorbed from the colon i.e. Pakwasaya. Basti karma helps to increase the absorbing capacity of the colon by its actions.

Behind the Pakwasaya, there are large numbers of nerve plexuses originating from the hypo gastric plexus and lumbo-sacral plexus etc. These plexus will get nourishment and soothing effect from Basti karma because Basti mainly acts on the Pakwasaya, here it nourishes, purifies and expels the unwanted toxins from the body.

Basti dravya prepared by Madhu, Sneha etc helps in formation of Krimis (friendly bacteria) in large intestine, some bacteria synthesizes vitamins like $\mathrm{B}$ and $\mathrm{K}$ which are essential for the maintenance and nourishment of nervous system probably to some extent.

Approximately $50 \%$ of the drugs that is absorbed from the rectum will bypass the liver, the potential foe hepatic first pass the rectum ${ }^{8}$. Another probable method is based on Veerya. It is possible the Veerya of the Basti dravya pass through the autonomic nervous system and expels out 
vitiated Dosha from the body. It is described in the modern physiology that the wall of the rectum has pressure receptors. Whenever the stool enters the rectum, these receptors are stimulated and the defecation reflex is initiated.

When Basti Netra is introduced in the rectum the same phenomenon may take place, which results in initiation of defecation reflex due to visceral distention and pressure response.

Saindhava which fulfills the requirement for generating action potential. The release of catecholamine occurs during visceral distention and probably this leads to the development of pressure response and ultimately the defecation reflex is initiated. Also, salt forms an integral part of the body fluids and its concentration governs the movement of fluids in various compartments under the osmotic pressure. When hypertonic solution is given in the form of Basti dravya the introduced fluid circulates from low density to high-density solution i.e. from blood vessels to the outer fluid in the gastro intestinal tract. ${ }^{9}$

As regard the absorption of Basti dravya, it is reported that the water soluble substance are absorbed $60 \%-80 \%$ from the gut and normal saline is absorbed freely. Amino acids are also reported to be absorbed.

\section{Overall Effect of the Therapy}

In assessing overall effect of therapy it was seen that out of 10 patients, $10 \%$ patient was cured. $60 \%$ patients got marked improvement and $30 \%$ patients were improved. None of the patients remained unchanged. Statistically highly significant results were obtained.

Table 1: Self Assessment Scoring System

\begin{tabular}{|c|c|c|c|}
\hline Sl. No & Signs and symptoms & Criteria & Score \\
\hline 1 & $\begin{array}{c}\text { Ruk } \\
\text { (Pain) }\end{array}$ & $\begin{array}{c}\text { No pain } \\
\text { Painful, walks without limping } \\
\text { Painful, walks with limping but without support } \\
\text { Painful, can walk only with support } \\
\text { Painful, unable to walk } \\
\text { Severe pain needs medications }\end{array}$ & $\begin{array}{l}0 \\
1 \\
2 \\
3 \\
4 \\
5\end{array}$ \\
\hline 2 & $\begin{array}{c}\text { Stambha } \\
\text { (Stiffness): }\end{array}$ & $\begin{array}{l}\text { No stiffness } \\
\text { Mild stiffness } \\
\text { Moderate stiffness } \\
\text { Severe stiffness }\end{array}$ & $\begin{array}{l}0 \\
1 \\
2 \\
3\end{array}$ \\
\hline 3 & $\begin{array}{c}\text { Toda } \\
\text { (Pricking Sensation) }\end{array}$ & $\begin{array}{l}\text { No pricking sensation } \\
\text { Mild pricking sensation } \\
\text { Moderate pricking sensation } \\
\text { Severe pricking sensation }\end{array}$ & $\begin{array}{l}0 \\
1 \\
2 \\
3\end{array}$ \\
\hline 4 & $\begin{array}{c}\text { Spandana } \\
\text { (Fasciculation) }\end{array}$ & $\begin{array}{l}\text { No fasciculation } \\
\text { Mild fasciculation } \\
\text { Moderate fasciculation } \\
\text { Severe fasciculation } \\
\end{array}$ & $\begin{array}{l}0 \\
1 \\
2 \\
3\end{array}$ \\
\hline 5 & $\begin{array}{c}\text { Aruci } \\
\text { (Anorexia) }\end{array}$ & $\begin{array}{c}\text { No anorexia } \\
\text { Mild anorexia } \\
\text { Moderate anorexia } \\
\text { Severe anorexia } \\
\end{array}$ & $\begin{array}{l}0 \\
1 \\
2 \\
3\end{array}$ \\
\hline 6 & $\begin{array}{c}\text { Tandra } \\
\text { (Torpor) }\end{array}$ & $\begin{array}{l}\text { No torpor } \\
\text { Mild torpor } \\
\text { Moderate torpor } \\
\text { Severe torpor } \\
\end{array}$ & $\begin{array}{l}0 \\
1 \\
2 \\
3\end{array}$ \\
\hline 7 & $\begin{array}{c}\text { Gaurava } \\
\text { (Heaviness) }\end{array}$ & $\begin{array}{l}\text { No heaviness } \\
\text { Mild heaviness } \\
\text { Moderate heaviness } \\
\text { Severe heaviness }\end{array}$ & $\begin{array}{l}0 \\
1 \\
2 \\
3\end{array}$ \\
\hline 8 & Straight leg raise test & $\begin{array}{l}\text { More than } 90^{\circ} \\
71^{\circ}-90^{\circ} \\
51^{\circ}-70^{\circ} \\
31^{\circ}-50^{\circ} \\
\text { up to } 30^{\circ} \\
\end{array}$ & $\begin{array}{l}0 \\
1 \\
2 \\
3 \\
4\end{array}$ \\
\hline 9 & Walking distance & $\begin{array}{l}\text { Pain does not prevent me walking any distance } \\
\text { Pain prevents me walking more than } 1 \text { mile. } \\
\text { Pain prevents me walking more than } 0.5 \text { miles } \\
\text { Pain prevents me walking more than } 0.25 \text { miles } \\
\text { I can only walk using a stick or crutches }\end{array}$ & $\begin{array}{l}0 \\
1 \\
2 \\
3 \\
4 \\
\end{array}$ \\
\hline 10 & Standing & $\begin{array}{l}\text { can stand as long as I want without extra pain } \\
\text { can stand as long as I want but it gives me extra pain } \\
\text { Pain prevents me from standing for more than } 1 \text { hour } \\
\text { Pain prevents me from standing for more than } 30 \text { minutes } \\
\text { Pain prevents me from standing for more than } 10 \text { minutes }\end{array}$ & $\begin{array}{l}0 \\
1 \\
2 \\
3 \\
4\end{array}$ \\
\hline
\end{tabular}




\section{B.A. Lohith et al / IJRAP 4(1), Jan - Feb 2013}

Table 2: Cardinal symptom wise distribution of 10 patients of Gridhrasi

\begin{tabular}{|c|c|c|}
\hline Signs and Symptoms & No. of Patients & $\%$ \\
\hline Ruk & 10 & 100 \\
\hline Toda & 10 & 100 \\
\hline Stambha & 8 & 80 \\
\hline Spandana & 04 & 40 \\
\hline Aruchi & 04 & 50 \\
\hline Tandra & 02 & 20 \\
\hline Gaurava & 04 & 40 \\
\hline Sakthanah Kshepam Nigrahaniyat (SLR test) & 10 & 10 \\
\hline Dehasyapi Pravakra (scoliosis) & 06 & 60 \\
\hline
\end{tabular}

Table 3: Results of the study

\begin{tabular}{|c|c|c|c|c|c|c|c|c|}
\hline \multirow{2}{*}{ Symptoms } & \multirow{2}{*}{ No. of patients. } & \multirow{2}{*}{\multicolumn{2}{|c|}{ Mean Score }} & \multirow{2}{*}{$\%$ relief } & \multirow{2}{*}{$\begin{array}{l}\text { S.D. } \\
( \pm)\end{array}$} & \multirow{2}{*}{$\begin{array}{c}\text { S.E. } \\
( \pm)\end{array}$} & \multirow{2}{*}{ 't' } & \multirow{2}{*}{$\mathrm{P}$} \\
\hline & & & & & & & & \\
\hline Ruk & 10 & 3.6 & 2.1 & 58.3 & 0.738 & 0.233 & 9.00 & $<0.001$ \\
\hline Toda & 8 & 2.3 & 1.0 & 60.0 & 0.943 & 0.298 & 3.354 & $<0.05$ \\
\hline Stambha & 6 & 2.6 & 1.7 & 65.3 & 0.675 & 0.213 & 7.90 & $<0.001$ \\
\hline Spandana & 3 & 0.50 & 0.25 & 50.0 & 0.463 & 0.164 & 1.524 & $>0.05$ \\
\hline Aruchi & 3 & 0.75 & 0.35 & 66.6 & 0.756 & 0.267 & 1.873 & $>0.05$ \\
\hline Tandra & 2 & 2.3 & 1.20 & 47.8 & 0.738 & 0.233 & 4.748 & $<0.05$ \\
\hline Gaurava & 7 & 2.3 & 1.4 & 60.8 & 0.516 & 0.163 & 8.573 & $<0.001$ \\
\hline SLR Test & 10 & 2.9 & 1.3 & 44.0 & 0.823 & 0.260 & 4.993 & $<0.001$ \\
\hline Standing & 10 & 3.2 & 1.9 & 59.0 & 0.738 & 0.233 & 8.143 & $<0.001$ \\
\hline Walking distance & 10 & 3.1 & 1.8 & 61.0 & 0.516 & 0.163 & 9.795 & $<0.001$ \\
\hline
\end{tabular}

\section{CONCLUSION}

Yoga Basti provided good relief in the symptoms of Toda, Stambha and Spandana. It also provided comparatively better relief in S.L.R test standing time and walking distance. Overall effects provided by Yogabasti were also better.

\section{REFERENCES}

1. Younes M, Bejia I, Aguir Z, Letaief M, Hassen-Zroer S, Touzi M, et al. Prevalence and risk factors of disc-related sciatica in an urban population in Tunisia. Joint Bone Spine 2006;73:538-42 http://dx.doi.org/10.1016/j.jbspin.2005.10.022 PMid:16725362

2. Agnivesha: Charaka Samhita, with Ayurveda Deepika Teekha by Chakarpani Dutta, Published by Chaukhambha Sanskrit sansthan, Varanasi, fifth edition p 696

3. Sushruta; Sushruta Samhita with Nibandhasarasangraha Commentary of Sri Dalhana Acharya and Nyaya Chandrika panjika of Sri Gayadasacharya; edited by Vaidya Yadavji Trikamji Acharya and Narayan Ram Acharya; Reprinted edition, 2003; Krishnadas Academy, Varanasi. Uttar Pradesh $6^{\text {th }}$ ed., 1997, p 255, 268, 420-21
4. Agnivesha: Charaka Samhita, with Ayurveda Deepika Teekha by Chakarpani Dutta, Published by Chaukhambha Sanskrit sansthan, Varanasi, fifth edition 1992, p 689

5. Agnivesha: Charaka Samhita, with Ayurveda Deepika Teekha by Chakarpani Dutta, Published by Chaukhambha Sanskrit sansthan, Varanasi, fifth edition 1992 p 696

6. Sharngadharacharya - Sharangadhara Samhita, commentary by Adhamalla's Dipika \& Kasirama's Gudhartha Dipika Ed. By Guruprasad Sharma, Sri krishana das academy Varanasi, 1986.

7. Vagbhata, Astanga Hridayam with the commentary Sarvanga Sundari and Ayurveda Rasayana, Edr. Bhishagacharya Harishastri Paradakara Vaidya, Chowkamba Orientalia, Varanasi, $8^{\text {th }}$ ed., 1998 , p 276, 416, 418

8. Goodman and Gillman, The pharmacological basis of therapeutics tenth edition 2001 on general principals. $p 7$

9. Dr Vasudevan Nampoothiri and Dr L Mahadevan, Principles and practice of Vasti 2006 published by Dr Y Mahadeva Iyers Sri Sarada Ayurvedic Hospital Derisanakoppa p172-175

Cite this article as:

B.A. Lohith, Girish K.J. Clinical study to assess the effect of Yoga basti in Gridhrasi. Int. J. Res. Ayur. Pharm. 2013; 4(1):50-53 